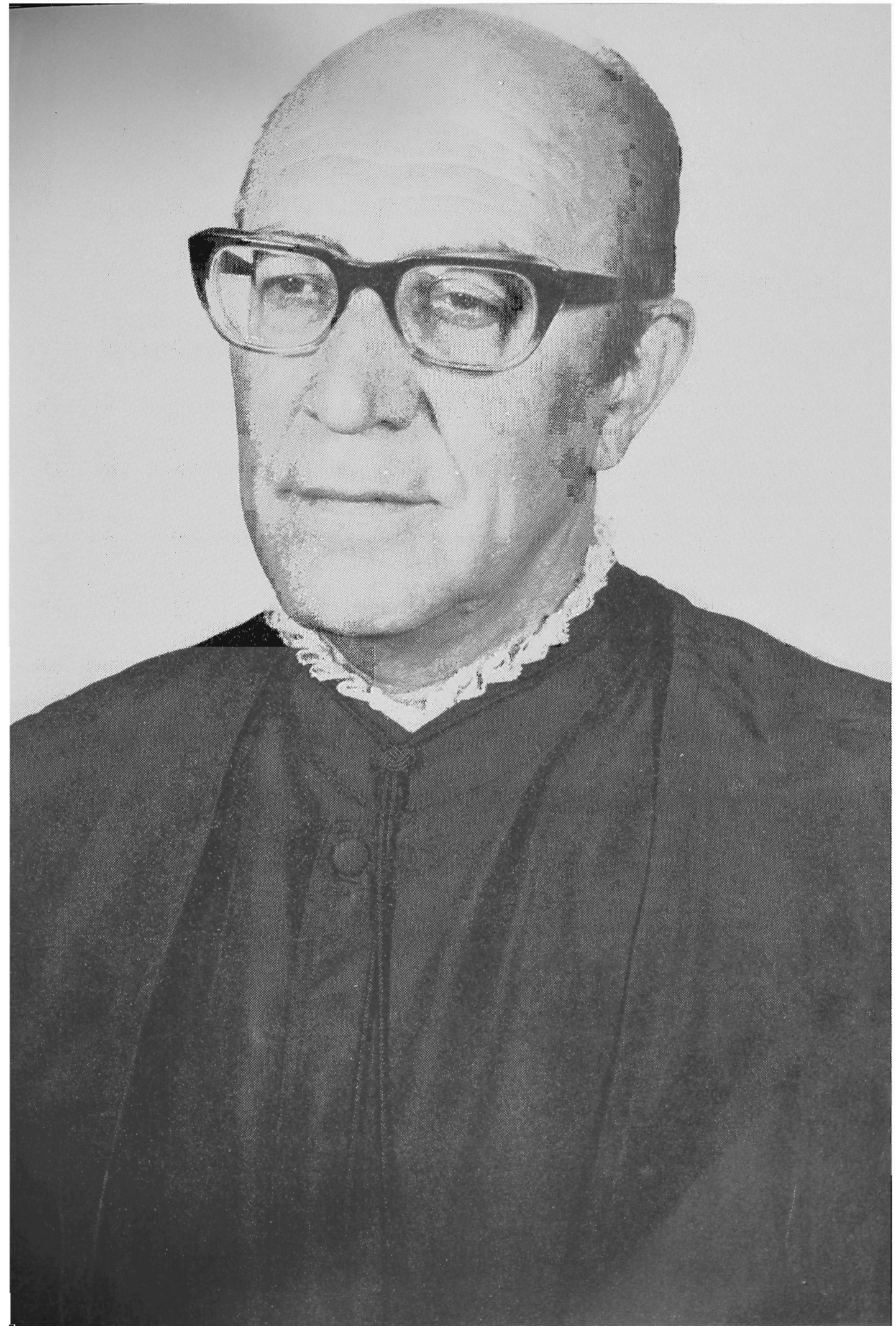


Professor Dr. Ruy Barbosa Nogueira, Diretor da Faculdade de Direito 


\section{Professor Dr. Ruy Barbosa Nogueira, Novo Diretor da Faculdade de Direito.}

O professor Dr. Ruy Barbosa Nogueira, filho de José de Anchieta Nogueira, já falecido, e de D. Maria Augusta de Magalhães Nogueira, nasceu em Jardinópolis, Estado de São Paulo, a 19 de setembro de 1919

Casou-se em 9 de junho de 1940 com D. Zoé de Mattos Cabral Nogueira, sendo seus filhos Dr. Paulo Roberto Cabral Nogueira e Dr. Rubens Cabral Nogueira.

Fez o curso primário em Batatais e o secundário parte no Ginásio São José desta cidade e mudando-se para São Paulo veio conclui-lo no Ginásio Oswaldo Cruz.

Matriculou-se no Colegio Universitário da Faculdade de Direito da USP, ingressando em 1941 no curso de bacharelado da mesma Faculdade, onde bacharelou-se em 1945 .

Em 1963 prestou concurso à livre docência de Direito Tributário na Faculdade de Direito da Universidade de São Paulo.

Em 1965 conquista, com brilhantismo, a cátedra de Direito Tributário da Faculdade de Direito da USP.

Atualmente é presidente da Comissão de Legislação e Recursos da USP, professor de Direito Tributário Comparado do curso de Pós Graduação, nos graus de Mestrado e Doutorado, da Faculdade do Largo de São Francisco e presidente do Instituto Brasileiro de Direito Tributário.

Autor de vários livros e trabalhos sobre o extenso campo dos diversos impostos, taxas e contribuições.

Conta ainda o professor Ruy Barbosa Nogueira com a mais ampla experiência não só como parecerista, mas como advogado militante, há quase 30 anos. 